
Pontifícia Universidade Citálica $_{\text {Do Rio de JaneIro }}$

Renato Matoso Ribeiro Gomes Brandão

A Ontologia de Sócrates nos Diálogos Platônicos Da busca por Definições às Críticas do Parmênides

Tese de Doutorado

Tese apresentada como requisito parcial para obtenção do título de Doutor pelo Programa de PósGraduação em Filosofia do Departamento de Filosofia da PUC-Rio.

Orientador: Profa. Irley Fernandes Franco

Rio de Janeiro

Setembro de 2014 


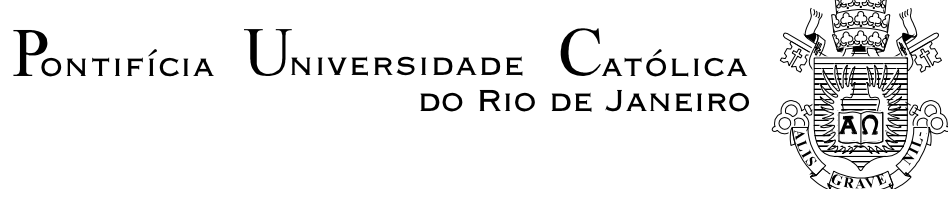

Renato Matoso Ribeiro Gomes Brandão

\title{
A Ontologia de Sócrates nos Diálogos Platônicos \\ Da busca por Definições às Críticas do Parmênides
}

\begin{abstract}
Tese apresentada como requisito parcial para obtenção do título de Doutor pelo Programa de Pós-Graduação em Filosofia do Centro de Teologia e Ciências Humanas PUC-Rio. Aprovada pela Comissão Examinadora abaixo assinada.
\end{abstract}

\author{
Profa. Irley Fernandes Franco \\ Orientadora \\ Departamento de Filosofia - PUC-Rio \\ Prof. Danilo Marcondes \\ Departamento de Filosofia - PUC-Rio
}

Prof. Gabriele Cornelli

Universidade de Brasília-UnB

Prof. Francisco J. Gonzales

University of Ottawa

Prof. Fernando Augusto da Rocha Rodrigues

Universidade Federal do Rio de Janeiro-UFRJ

Profa. Denise Berruezo Portinari Coordenadora Setorial do Centro de Teologia e Ciências Humanas - PUC-Rio

Rio de Janeiro, 23 de setembro de 2014 
Todos os direitos reservados. É proibida a reprodução total ou parcial do trabalho sem autorização da universidade, do autor e da orientadora.

\section{Renato Matoso Ribeiro Gomes Brandão}

Concluiu o Bacharelado em Filosofia pela PUC-Rio em 2006 e mestrado em 2009, pela mesma instituição. Possui pesquisas nas áreas de Filosofia Antiga, Ontologia e Filosofia da Linguagem com diversos trabalhos apresentados em seminários e artigos publicados em periódicos especializados.

Brandão, Renato Matoso Ribeiro Gomes

A ontologia de Sócrates nos diálogos platônicos: da busca por definições às críticas do parmênides / Renato Matoso Ribeiro Gomes Brandão ; orientador: Irley Franco. - 2014.

$311 \mathrm{f}$; ; $30 \mathrm{~cm}$

Tese (doutorado)-Pontifícia Universidade Católica do Rio de Janeiro, Departamento de Filosofia, 2014.

Inclui bibliografia

1. Filosofia - Teses. 2. Teoria das ideias. 3. Ontologia. 4. Diálogos platônicos. 5. Parmênides. I. Franco, Irley. II. Pontifícia Universidade Católica do Rio de Janeiro. Departamento de Filosofia. III. Título. 
A Deus, meus pais, meus irmão, meus sobrinhos e meu amor. 


\section{Agradecimentos}

Gostaria de agradecer a meus pais que sempre me apoiaram na difícil tarefa de pensar, pesquisar, criticar e escrever. Tarefa esta que, infelizmente, ainda é vista como desperdício de tempo e talento em um mundo cada vez mais apegado a tudo aquilo que é fugaz e transitório.

Agradeço a meus irmãos Leonardo e Clarissa por me oferecerem a confiança do amor fraterno, sempre disposto a ajudar em qualquer momento de aflição.

Agradeço a meus sobrinhos João e Artur por me demonstrarem todos os dias o que é a pureza e a felicidade.

Agradeço à Nastassja Saramago pelo carinho, suporte e amor constante e eterno, pelos inspiradores comentários e debates sobre este trabalho e sobre tudo aquilo que está ligado à Filosofia e à vida intelectual.

Agradeço ao Pe Paul Schweitzer S. J. grande fonte de inspiração para todos que o conhecem e que há muito ajuda a mim e minha família a reconhecer os desígnios de Deus e a beleza do mundo nos acidentes da vida.

Agradeço, à Profa. Maura pelas aulas inspiradoras que tenho a sorte de acompanhar desde minha graduação e pela orientação dedicada. Assim como a todos os professores do Departamento de Filosofia da Puc-Rio pelo exemplo de conhecimento, companheirismo e fineza de trato.

Agradeço à Profa Irley Franco pela orientação nos momentos decisivos, pela ajuda e pelos exemplos cotidianos de companheirismo e amizade.

Agradeço à Profa. Mary-Louise Gill pela orientação e carinho a mim dispensados nas duas ocasiões em que estive na Brown University, durante o período de pesquisa e redação deste trabalho.

Agradeço ao CNPq pelo financiamento de meu doutorado e à CAPES por financiar um período de estágio na Brown University. Sem ambos estes apoios, esta Tese não poderia ser escrita.

Por fim, gostaria de agradecer aos administradores do Departamento de Filosofia que, na figura da sempre amável Edna Sampaio há uns bons anos me ajudam até mais do que se poderia esperar. 


\section{Resumo}

Brandão, Renato Matoso Ribeiro Gomes; Franco, Irley Fernandes. A ontologia de Sócrates nos diálogos platônicos: da busca por definições às críticas do Parmênides. Rio de Janeiro, 2014. 311p. Tese de Doutorado - Departamento de Filosofia, Pontifícia Universidade Católica do Rio de Janeiro.

A tese pretende investigar a ontologia defendida pelo personagem Sócrates nos diálogos platônicos. Em oposição à interpretação majoritariamente aceita, que atribui ao personagem Sócrates a adesão a duas ontologias distintas, defendo a hipótese de que o Sócrates dos diálogos platônicos argumenta consistentemente a partir de uma única proposta ontológica. Esta proposta consiste na postulação de entidades inteligíveis realmente existentes que atuam como causa das propriedades dos objetos sensíveis. A tese divide-se em duas partes. Na primeira parte, começo por analisar as particularidades da composição platônica, assim como a formação do paradigma atual de leitura das obras de Platão. Em um segundo momento, tomo como foco os diálogos iniciais e defendo que a ontologia subjacente à argumentação de Sócrates nestas obras é a mesma que encontramos nos diálogos médios. No último capítulo da primeira parte, apresento a argumentação socrática dos diálogos médios e demonstro como, nestas obras, a ontologia dos diálogos iniciais é apresentada de maneira explícita e mais informativa. A segunda parte da tese consiste em uma análise das críticas à Teoria das Ideias que encontramos no diálogo Parmênides. No primeiro momento desta segunda parte, argumento que o Sócrates do Parmênides está, novamente, defendendo a mesma proposta ontológica dos diálogos médios e iniciais. Posteriormente, demonstro como as críticas formuladas pelo personagem Parmênides são válidas e realmente apresentam problemas relevantes para teoria socrática.

\section{Palavras-chave}

Teoria das Ideias; Ontologia; Diálogos Platônicos; Parmênides. 


\section{Abstract}

Brandão, Renato Matoso Ribeiro Gomes; Franco, Irley Fernandes (Advisor). The Ontology of Socrates in the Platonic Dialogues: from the search for definitions to the criticism of the Parmenides. Rio de Janeiro, 2014. 311p. Doctoral Thesis - Departamento de Filosofia, Pontifícia Universidade Católica do Rio de Janeiro.

This dissertation aims to investigate the ontology proposed by the character Socrates in the Platonic dialogues. In opposition to the mostly accepted interpretation which attributes to the character Socrates the adoption of two distinct ontologies, I defend the hypothesis that the Socrates of the Platonic dialogues consistently argues from within a single ontological theory. This theory consists in the postulation of real and existing intelligible entities that act as the cause of the properties of sensible objects. The dissertation is divided in two parts. In the first part, I analyze the particularities of the Platonic composition as well as the construction of the actual reading paradigm of the Platonic works. In a second moment, I start investigating the first dialogues and claim that the ontological theory that underlies Socrates' arguments in these works is the same as the one we can find in the middle dialogues. In the last chapter of the first part, I expose the Socratic arguments from the middle dialogues and I show how, in these woks, the underlying ontology of the first dialogues is more explicitly and informatively presented. The second part of the dissertation consists in an analysis of the critiques of the Theory of Forms that we find in the Parmenides dialogue. In the first moment of this second part, I argue that the Socrates from the Parmenides is again defending the same ontological theory from the middle and first dialogues. Afterwards, I show how the critiques constructed by the character Parmenides are valid and do present significant problems to the ontological theory of Socrates.

\section{Keywords}

Theory of Forms; Ontology; Platonic Dialogues; Parmenides. 


\section{Sumário}

Introdução

1. A Origem do Paradigma Desenvolvimentista de Interpretação dos Diálogos de Platão

1.1. O Schleiermacher: a noção de evolução expositiva

1.2. Hermann: a noção de historicidade na interpretação da obra platônica

1.3. O método estilométrico 27

1.4. A apropriação indevida dos resultados estilométricos 36

1.5. A hipótese de uma fase socrática nos diálogos de Platão 40

1.6. Conclusão do primeiro capítulo 44

2. A Ontologia dos Diálogos Socráticos

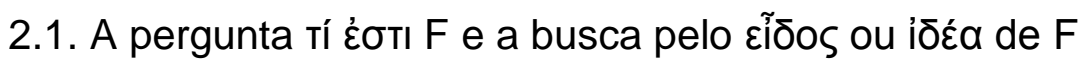

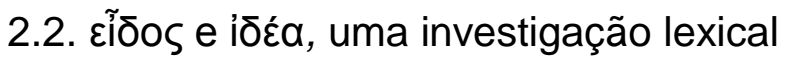

2.3. Confundindo Universais e Particulares

2.4. As exigências socráticas: co-extensividade 71

2.5. As exigências socráticas: relação causal 81

2.6. Duas interpretações para pergunta tí દ̇oтı F 87

2.7. Causalidade explicativa e a imanência das Formas 96

2.8. A ontologia de Sócrates nos diálogos em busca de definições 103

2.9. A ontologia de Sócrates nos diálogos de juventude 110

2.10. Conclusão do segundo capítulo 119 
3.1. O discurso de Diotima e a revelação da Forma do Belo 127

3.2. A inteligibilidade das Formas 138

3.3. A natureza relacional dos objetos sensíveis 142

3.4. Formas, objetos sensíveis e propriedades imanentes $\quad 150$

3.5. A imperfeição das entidades sensíveis 158

3.6. O poder causal das Formas 164

3.7. Conclusão do terceiro capítulo 170

4. O Diálogo Parmênides e a Ontologia Socrática 174

4.1. Apresentação do diálogo Parmênides 174

4.1.1. A Posição do Parmênides no interior da obra de Platão 181

4.1.2. O Prólogo do Parmênides 184

4.1.3. O paradoxo de Zenão 188

4.1.4. Dois sentidos de multiplicidade e unidade implicados na argumentação zenoniana $\quad 190$

4.1.5. A redução ao absurdo da tese pluralista 196

4.1.6. A solução de Sócrates para o paradoxo de Zenão 200

4.1.7. O desafio de Sócrates 208

4.2. As críticas de Parmênides à teoria da participação 217

4.2.1. A separação das Formas 222

4.2.2. A extensão do conjunto de Formas 228

4.2.3. O dilema da Participação 234

4.2.4. A estrutura do dilema de participação 238

4.2.5. Participação no todo da Forma 242

4.2.6. Participação em partes da Forma 244

4.2.7. A validade do dilema da participação como crítica à Teoria das Ideias 
4.3. O Argumento do Terceiro Homem e a multiplicação infinita das Formas

4.3.1. A formalização do Argumento do Terceiro Homem 265

4.3.2. A auto-predicação das Formas 274

4.4. Conclusão do quarto capítulo 293

5. Conclusão 297

6. Referências Bibliográficas 299 


\section{OY TA ПANTA TOI $\Sigma$ ПA}

"Não se pode ensinar tudo a todos."

- Pitágoras de Samos (atrib.) 